\title{
Organizational Development Interventions In Learning Organizations
}

John Theodore, Ph.D., DBA, Ph.D., CMC, President, JDT Management Consultants, USA

\begin{abstract}
The purpose of this article was to demonstrate that organizational development interventions in key areas of learning organizations assist to further develop such organizations because they are open systems and accustomed to planned changes. Therefore, their resistance to planned developmental changes is limited in comparison to non-learning organizations that are not accustomed to this process. The ultimate goal of organization development is to make the organization more open and more adaptive through increases in capability and potential in order for it to continue making such planned change efforts on an action orientation basis. Learning organizations are viable and vital means for developing an organization's culture of high performance learners who become transformed people much better adapted to get results that affect the bottom line and the quality of life in their organizations. The author of this article focused organizational development interventions on a number of key areas in learning organizations which are: human resources policies and procedures, evaluation of human resources, structure and design, training and development of human resources, communication, and leadership. In this article, the above cited areas are referred to as concentrations. The organizational development intervention process consists of the diagnosis in order to identify the elements to be evaluated in the areas of concentration; the presentation of the results of the diagnoses in proposals for the implementation of the results; and the implementation through planned change efforts.
\end{abstract}

Keywords: Organizational Development; Learning Organizations; Training and Development

\section{INTRODUCTION}

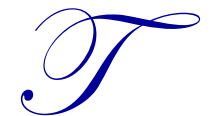

he purpose of this article was to demonstrate that organizational development interventions in key areas of learning organizations assist to further develop such organizations because they are open systems and accustomed to planned developmental changes. Therefore, their resistance to planned developmental changes is limited or absent in comparison to non-learning organizations that are not accustomed to this process.

\section{LEARNING ORGANIZATIONS}

Learning organizations are viable and vital means for developing an organization's culture of high performance learners who become transformed people much better adapted to get results that affect the bottom line and the quality of life in their organizations (Kline \& Saunders, 1998).

Learning organizations are entities where people continually expand their capacities to create the results they truly desire, environments where new and expansive patterns of thinking are nurtured, entities designed to set free collective aspirations and where people are continually learning to see the whole together (Senge, 1990). In other words, learning organizations' perception is holistic rather than fragmented (Theodore, 2012). 


\section{ORGANIZATIONAL DEVELOPMENT}

Organization development is a planned change effort which involves all the parts of the organization. It is initiated and managed from the top hierarchy of the system and is designed to increase organizational effectiveness (Schein, 1985). The ultimate goal of organization development is to make the organization more open and more adaptive through increases in capability and potential in order for it to continue making such planned change efforts on an action orientation basis (French, \& Bell, 1978).

\section{ORGANIZATIONAL DEVELOPMENT INTERVENTIONS}

The author of this article focused on a number of key areas in learning organizations which are: human resources policies and procedures, evaluation of human resources, structure and design, training and de velopment of human resources, communication, and leadership. In this article, the above cited areas are referred to as concentrations. He proposed that by focusing on these concentrations and by implementing organizational development interventions through them, learning organizations will be subject to continuous development through transformational change (Nevis, DiBella, and Gould, 1995).

Argyris and Schon (1978) indicated that an intervention is the process that enters into ongoing relationships for the purpose of being able to help and that such help is to increase the capacity for organizational inquiry which engages those mistakes, incongruities, and incompatibilities in organizational theory of action which necessarily emerge as the organization system and environment change. Organizational development interventions need to be continuous on an action orientation basis (Lewin, 1951).

The intervention process has three distinct steps which are the diagnosis in order to identify the elements to be evaluated in the areas of a concentration, the presentation of the results of the diagnosis in the form of proposals for the implementation of the results, and the implementation of the proposals through planned change efforts (Beckhard, 1969). These three intervention steps are conducive to the change of the status quo (Burke, 1994). The results of the findings of the various diagnoses are used for the correction of the deficient and/or dysfunctional elements in each concentration and for the subsequent developmental changes of the elements that exist in each and all concentrations (Argyris, 1991).

\section{Human Resources Policies and Procedures}

Rules and regulations are better known as policies and procedures. Policies are guides that dictate the parameters within which persons, groups, and organizational units must operate in order to accomplish their goals (Theodore, 2002).

Policies create the framework for implementing organizational strategies, whereas procedures dictate how tasks need to be executed in order to implement such strategies. Policies and procedures are related to the mission, goals, and objectives of the organization and provide guidance for daily work, decision-making, and rewarding behavior by establishing the base for systems of internal control. Human resources policies are pertinent to the selection and development of the human element employed in the organization (Noe, Hollenbeck, Gerhart, \& Wright, 2010).

The goal of the intervention in this concentration is to create current, accurate, ethical, realistic, and legally correct policies and procedures conducive to the recruitment and development of human resources leading to a Theory Y organizational environment (McGregor, 1960) and to the satisfaction of their needs (Maslow, 1954). The diagnosis has to do with the evaluation of existing human resources policies, and procedures.

\section{Evaluation of Human Resources}

Performance appraisal refers to the systematic description and review of an individual's job performance in order to improve organizational performance (Bowin \& Harvey, 2001). Because performance evaluation is related to 
the organization's mission, goals, and objectives, it is an integral element for the improvement of the overall organizational performance (Bohlander, Snell, \& Sherman, 2001).

The goal of the intervention in this concentration is to acquire personnel correctly and to increase the efficiency and effectiveness of the human resources in performing their tasks through reinforcing, sustaining, and improving performance. The diagnosis focuses on the evaluation of the preparation and function of those who conduct evaluations; how the performance evaluations are conducted; the types, instruments, methods, procedures, and techniques of performance evaluations; and the legal, social, and ethical considerations in performance evaluations.

\section{The Structure and Design}

The organizational design indicates how an organization abides by its internal congruence and configuration while it receives inputs from and provides outputs to the external environment (Bennis \& Natus, 1985). Congruence is the organizational effectiveness which results when the organization is adapted to its external environment (Kreitner, 2001). Organizational configuration, on the other hand, is the effectiveness based upon the internal coherence of its various elements that exist in the concentrations listed in this article (Theodore, 2011). The organizational structure defines relationships among organizational elements, tasks, personnel, hierarchy, communication, and control (Hodge, Anthony, \& Gales, 2003).

The goal of the intervention in this concentration is to develop positional roles and relationships that cause more effective and efficient arrangements in tasks, resources, and hierarchal responsibilities. The diagnosis focuses on evaluation of inputs/outputs; departmentalization (including job design); authority and responsibility of persons and departments, as well as the delegation of authority and responsibility under parity; unity of command; span of control; and line and responsibilities and relationships.

\section{Training and Developing the Human Resources}

Management training and development provide the knowledge and skills managers need to perform their jobs effectively. Training focuses on the improvement of current managerial jobs and the acquisition of knowledge and skills. Development has to do with building the knowledge and skills so that managers will be prepared to assume new responsibilities (Anderson, 2010). Management training and development necessitates actual practice and experience, especially for the development of the upper middle and top managerial echelons.

Employee training and development is a continuing process involving all aspects of the non-managerial employee's jobs, careers, and working environment. It is designed to ensure that employees are properly trained and developed so that organizational goals are met. This practice begins with the selection process and continues throughout the employees' affiliation with the organization. Training, psychological support, and participation all increase the likelihood that employees will understand and feel comfortable with organizational changes (Bolman \& Deal, 2008).

The goal of the intervention in this concentration is to assist the management to develop their technical, human relations, and conceptual skills and support the employees to perform more effectively and efficiently their functional tasks. The diagnosis in this concentration focuses on the evaluation of the training needs of managers in planning, organizing, staffing, directing, controlling their subordinates, and monitoring the environment; the evaluation of the training needs of the employees in their respective functional units where their tasks are performed; and the evaluation of the satisfaction of the employees and managers' needs based on Maslow's Theory of the Hierarchy of Needs.

\section{Communication}

Communication has to do with encoding of information by the sender, the passage of information to the receiver, and the decoding of the information by the receiver. Organizational communication is vertical and horizontal (Krizan et al 2008). Vertical communication flows up and down the organization, along formal reporting 
lines (Jones \& George, (2007). Horizontal communication flows laterally and involves individuals of the same rank, both within the same department and among departments. It facilitates coordination among the group members and among groups, and strengthens the decision-making process in both entities (Bohlander, Snell, \& Sherman, 2001).

The goal of intervention in this concentration is to develop (a) communication within the same department (intra-departmental) in order to help its members better understand their functional roles, and to make better decisions by analyzing available data effectively and efficiently. Furthermore, the intervention's purpose is to improve (b) communication and coordination among the members of various departments (inter-departmental).

The diagnosis in the intra-departmental concentration has to do with the analysis and evaluation of oral, written, formal, and informal communication; feedback; communication channels; and the decision-making process. On the other hand, the diagnosis in the inter-departmental concentration deals with the evaluation of formal and written communication; communication channels; feedback; and the evaluation of the perception of individuals and groups located in each unit toward one another.

\section{Leadership}

Leadership is the process of influencing others to achieve organizational goals. It involves a process whereby intentional influence is exerted over other people to guide, structure, and facilitate activities and relationships in a group or organization (Yukl, 2010). According to Yukl the characteristics of the leader are traits, confidence and optimism, skills and expertise, behavior, integrity, influence tactics, and attributions about followers. The human resource leader believes that people are the center of any organization and his/her job is to support and empower them (Bolman \& Deal, 2008).

The goal of the intervention in this concentration pivots around the leader's developmental needs and qualifications. The diagnosis focuses on the evaluation of the leader's current leadership needs and his/her qualifications specified in the previous paragraph.

\section{CONCLUSIONS}

The purpose of this article was to demonstrate that organizational development interventions in key areas of learning organizations assist to further develop such organizations because they are open systems and accustomed to planned developmental changes. Learning organizations are viable and vital means for developing an organization's culture of high performance learners. Organization development is a planned change effort which involves all the parts of the organization. The author focused on a number of key areas in learning organizations which are: human resources policies and procedures, evaluation of human resources, structure and design, training and development of human resources, communication, and leadership. The intervention process consists of the diagnosis in order to identify the elements to be evaluated in the areas of a concentration; the presentation of the results of the diagnoses in the form of proposals for the implementation of the results; and the implementation of the proposals through planned change efforts.

\section{AUTHOR INFORMATION}

John Theodore is the holder of a Ph.D. degree in Administration and Latin American Studies from the University of Kansas; a Ph.D. in Management from the Aristotelian University in Greece, European Union; and a D.B.A. in International Business from the University of South Africa. He has been teaching and consulting for four decades domestically and internationally. He is a visiting professor in various foreign universities. Dr. Theodore is the president of JDT Management Consultants in Clearwater, Florida, specializing in management, organization, strategy, international business, human resources, organizational development, and educational administration. He is a certified management consultant (CMC) certified by the Institute of Management Consultants in Washington, D.C. E-mail: jdtheodore@tampabay.rr.com 


\section{REFERENCES}

1. Anderson, D. L. (2010). Organization development: The process of leading organizational change. Thousand Oaks, CA: Sage Publications, Inc.

2. $\quad$ Argyris, C. (1991). Management and organization development. New York; McGraw-Hill.

3. Argyris, C., \& Schon, D. A. (1978). Organizational learning: A theory of action perspective. Reading, MA: Addison-Wesley Publishing Company.

4. Beckhard, R. (1969). Organization development: Strategies and models. Reading, MA: Addison-Wesley Publishing Company.

5. $\quad$ Bennis, W. G., \& Nanus, B. (1985). Leaders: The strategies of taking charge. New York: Harper and Row.

6. Bohlander, G. W., Snell, S., \& Sherman, A. W. (2001). Managing human resources. (12th ed.). Cincinnati, $\mathrm{OH}$ : South-Western College Publisher.

7. Bolman, L. G., \& Deal, T.E. (2008). Reframing organizations: Artistry, choice, and leadership. San Francisco: John Wiley \& Sons.

8. Bowin, R. B. \& Harvey, D. F. (2001). Human resource management: An experiential approach. Upper Saddle River, NJ: Prentice Hall.

9. Burke, W. W. (1994). Organization development: A process of learning and changing. ( $2^{\text {nd }}$ ed.). Reading, MA: Addison-Wesley Publishing Company.

10. French, W. L., \& Bell, C. H. (1978). Organization development: Behavioral science interventions for organization improvement. ( $2^{\text {nd }}$ ed.). Englewood Cliffs, NJ: Prentice Hall.

11. Hodge, B. J., Anthony, W. P., \& Gales, L. M. (2003). Organization theory: A strategic approach. (6 $6^{\text {th }}$ ed.). Upper Saddle River, NJ: Prentice Hall.

12. Jones, G. R., \& George, J. M. (2007). Essentials of contemporary management. (2 ${ }^{\text {nd }}$ ed.). Boston: McGrawHill Irwin.

13. Kline, P., \& Saunders, B. (1998). Ten steps to a learning organization ( $2^{\text {nd }}$ ed.). Salt Lake City, UT: Great River Books.

14. Kreitner, R. (2001). Management. ( $8^{\text {th }}$ ed). Boston: Houghton Mifflin Company.

15. Krizan, A. C., Merrier, P., Logan, J. \& Williams, K. (2008). Business Communication. (7 ${ }^{\text {th }}$ ed.). Mason, $\mathrm{OH}$ : Thomson South-Western.

16. Lewin, K. (1951). Field theory in social science. New York: Harper.

17. Maslow, A. H. (1954). Motivation and personality. New York: Harper and Brothers.

18. McGregor, D. (1960). The human side of enterprise. New York: McGraw-Hill.

19. Nevis, E. C., DiBella, A. J., and Gould, J.M (1995). Understanding organizations as learning systems. Sloan Management Review, 36(2), 73-85. Retrieved from http://search.proquest.com/docview/224967397? accountid=35797

20. Noe, R.A., Hollenbeck, J.R.,Gerhart, B.,\& Wright, P.M. (2010). Human resource management. (2nd ed.). New York: McGraw-Hill Irwin.

21. Senge, P. M. (1990). The fifth discipline: The art and practice of the learning organization. New York: Currency Doubleday Books.

22. Schein, E. H. (1985). Organizational culture and leadership. San Francisco:

23. Theodore, J. (2002). Organization Development: Target Areas and Goals for Planned Change Interventions. Central: The New Zealand Institute of Management. March-April. 52-65

24. Theodore, J. D. (2011). Culture and the development of management: An International example. Richmond, CA: Lyseis Public Policy Publishing.

25. Theodore, J. (March, 2012). Learning organizations, the American employee and manager, and the developmental role of the social sciences. Global Journal of Management and Business Research. Volume 12, Issue 4, Version 1.0

26. Yukl, G. A. (2010). Leadership in organizations. Upper Saddle Creek River, NJ: Person Prentice Hall. 


\section{NOTES}

